\title{
GEOTHERMAL DEVELOPMENT PLAN: PINAL COUNTY
}

\author{
Prepared by \\ The Arizona Geothermal Commercialization Team \\ Don H. White, Ph.D., Principal Investigator \\ Larry A. Goldstone, Project Manager \\ Arizona Geological Survey \\ Open-File Report 79-11
}

\section{Arizona Geological Survey}

416 W. Congress, Suite \#100, Tucson, Arizona 85701

State Contractor:

Arizona Solar Energy Commission

James F. Warnock, Jr., Director

Frank Mancini, Ph.D., Associate Director

1700 West Washington Phoenix, Arizona 85007

Work performed under

Contract No. DE-FC03-80RA50076, Modification No. A-001

Evaluation of Geothermal Energy in Arizona

U.S. Department of Energy San Francisco Office Region IX

Subcontract 114-80 with

Department of Chemical Engineering

University of Arizona Tucson, Arizona 85721

This report is preliminary and has not been edited

or reviewed for conformity with Arizona Geological Survey standards 


.




\section{ACKNOWLEDGEMENTS}

The Arizona Geothermal Commercialization Team has been comprised of many individuals over the past several years. Recognition is extended to the following professors who have contributed to the Team's efforts: John Kessler, Ph.D.; Mike Pasqualetti, Ph.D.; and David Wolf, Ph.D:

Group leaders were Mohamad Chehab, Larry Goldstone, Lani Malysa and Bill Weibel.

Other contributors include Cherif Ballamane, Ronda Bitterli, Wei-hsin (Alex) Chung, Elizabeth Foster, Jeff Hagen, Akram Hasan, Greta Jensen, Gary Kyle, Timeral Rowe, Edward Seames and John Westover.

The following people were special task contributors: Don Astrom, Greta Jensen, Iftikhar Khan, Doug Linkhart, Lani Malysa, Mobin Qaheri, Xavier Suarez, Charles Tabet and Steve Unguran.

In addition, W. Richard Hahman, Sr., Claudia Stone and Jim Witcher of the Arizona Bureau of Geology and Mineral Technology-Geothermal Group deserve recognition for their contributions and assistance.

Special thanks are extended to Bette Holt for drafting some of the figures and to Peggy Jackson and Lee DeYonghe for their assistance in typing the final manuscript. 
TABLE OF CONTENTS

Page

LIST OF FIGURES . . . . . . . . . . . . . . . . . . . 1 . 1

LIST OF TABLES . . . . . . . . . . . . . . . . . . . i i

INTRODUCTION . . . . . . . . . . . . . . . . . 1

AREA DEVELOPMENT PLANS . . . . . . . . . . . . . . 2

GEOTHERMAL RESOURCES ................... . . . 2

ECONOMY . . . . . . . . . . . . . . . . . . .

Population . . . . . . . . . . . . . . . . . . 6

Growth . . . . . . . . . . . . . . . . . . . . 6

Industry and Employment . . . . . . . . . . . . 8

Income . . . . . . . . . . . . . . . . . . . . . . 9

Other Economic Indicators . . . . . . . . . . . . . 9

LAND OWNERSHIP . . . . . . . . . . . . . . . 9

ENERGY USE . . . . . . . . . . . . . . . . . . 12

WATER ................................. 13

MATCHING GEOTHERMAL RESOURCES TO POTENTIAL USERS . . . . . . . 15

APPENDIX A . . . . . . . . . . . . . . . . . 22

BIBLIOGRAPHY . . . . . . . . . . . . . . . . . 24 


\section{LIST OF FIGURES}

Figure

Page

1 Area Development Plans for Arizona 3

2 Arizona's Proven, Potential and Inferred Resources

3 Population Projections for Pinal County 7

4 Employment Sector Projections for Pinal County 10

5 General Land Ownership Map for Pinal County 11

6 Projected Alternatives for Water Use in Pinal County 14

7 Projected Geothermal Heat On Line Under Private Development 16

8 Projected Geothermal Heat On Line Under City Development $\quad 17$ 


\section{LIST OF TABLES}

Table

Page

1 Some Common Conversion Factors

2

2 Proven and Potential Reservoirs of Pinal County of Less Than 1.2 Kn Depth

3 Major Towns in Pinal County and Their Current and Projected Populations

4 Breakdown of Land Ownership in Pinal County

5 Energy-Use Projections for Pinal County

6 Estimated Average Energy Prices by User Class, 1979

7 Estimated Process Heat Energy Requirements

8 Barrels of Oil Replaced by GeothermaI Energy Per Year Process Heat Market

9 Number of Firms Within Various Agricultural Sectors for Some Cities in Pinal County

10 Energy Use in the Prepared Feeds Segment 
INTRODUCTION

Alternative sources of energy will have to be developed as the availability of traditional energy resources continues to diminish. Arizona is supplied with geothermal reserves which could potentially supplement the existing energy supplies. Consequently, planning efforts have concentrated on estimating the potential of geothermal energy utilization in Arizona and in providing information necessary for its prospective commercialization.

Geothermal commercialization plans were prepared for seven distinct intrastate subdivisions. The geothermal resource prospect and the potential geothermal uses for each area are discussed in separate Area Development Plans (ADPs). The major objective of the ADP is to provide information for the prospective development and commercialization of geothermal energy in the specified area. Attempts are made to match the available geothermal resources to potential residential, commercial, industrial and agricultural users.

This ADP is concerned with geothermal potential in Pinal County. Wells drilled in the county provide evidence of geothermal energy sufficient for process heat and space heating and cooling applications. Annual energy consumption was estimated for industries whose process heat requirements are less than $105^{\circ} \mathrm{C}\left(221^{\circ} \mathrm{F}\right)$. This information was then used to model the introduction of geothermal energy into the process heat market. Also, agriculture and agribusiness industries were identified. Many of these are located on or near a geothermal resource and might be able to utilize geothermal energy in their operations. 


\section{AREA DEVELOPMENT PLANS}

Arizona has been divided into seven distinct single or multicounty subdivisions for which Area Development Plans (ADPs) for geothermal commercialization have been developed. A map of Arizona presented in Figure 1 shows these areas which are numbered in order of planning priority. This ADP is concerned with Pinal County. Both metric and English units are provided in the text. However, only metric units appear in the tables and figures. For convenience, some common conversion factors are listed in Table 1.

TABLE 1: SOME COMMON CONVERSION FACTORS

Length and Volume Conversions:

\begin{tabular}{lcl} 
To Convert: & Multiply By: & To Obtain: \\
\cline { 2 - 3 } meters & 3.281 & feet \\
kilometers & 0.6214 & miles \\
cubic kilometers & 0.2399 & cubic miles \\
liters & 0.2642 & gallons \\
Temperature Conversions: & ${ }^{\circ} F=\left(1.8 \times{ }^{\circ} \mathrm{C}\right)+32$.
\end{tabular}

GEOTHERMAL RESOURCES

Four areas of proven geothermal resources of less than $90^{\circ} \mathrm{C}\left(194^{\circ} \mathrm{F}\right)$. are located within Pinal County. Numbered boxes in Figure 2 identify these areas; Table 2 gives the location of each of these areas along with rough depth, volume and temperature estimates.

Thirty-eight wells drilled in Pinal County have surface water temperatures ranging from $35.0^{\circ} \mathrm{C}\left(95^{\circ} \mathrm{F}\right)$ to $71.7^{\circ} \mathrm{C}\left(161^{\circ} \mathrm{F}\right)$; well depths range from $84 \mathrm{~m}(276 \mathrm{ft})$ to $995 \mathrm{~m}(3265 \mathrm{ft})$. Most of these wells are located in 


\section{Priorities}

I) MaIfopa

II) Pina

III) Graham/Greenlee

IV) PInal

V) Tima

VI) Cochise/Santa Cruz

VII) Northern Counties $(1,3,4,8,9,13)$

\section{County Names}

1. Apache

2. Cochise

3. Coconino

4. GIIa

5. Graham

6. Greenlee

7. Maricopa

8. Mohave

9.- Navajo

10. Pima

11. Final

12. Santa Cruz

13. Yavapa1

14. Yuma

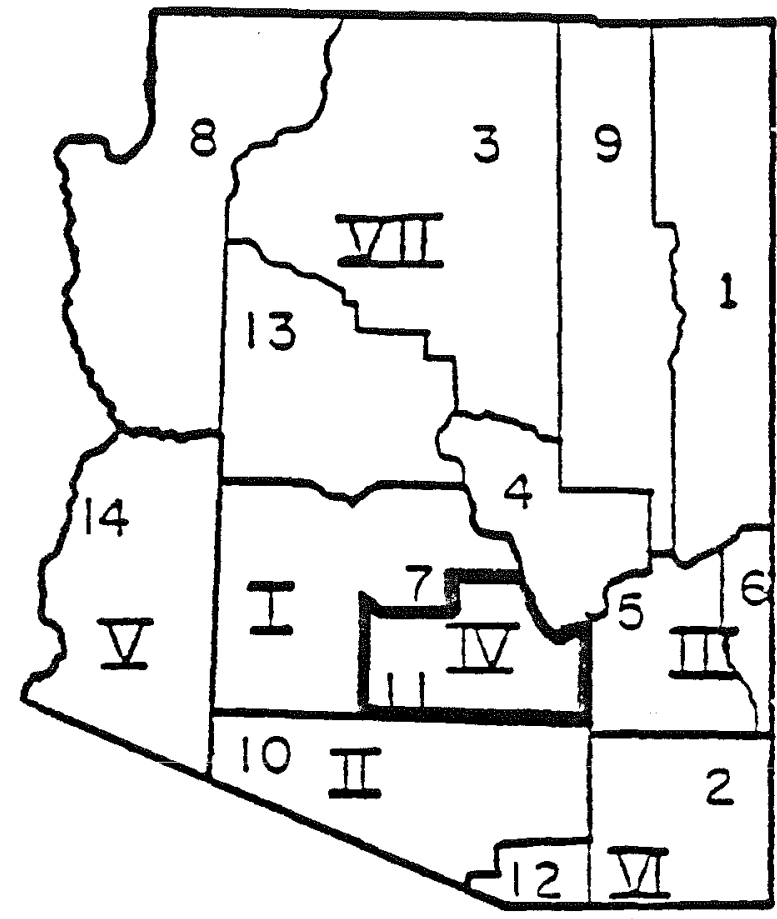

Figure 1: Area Development Plans for Arizona. 


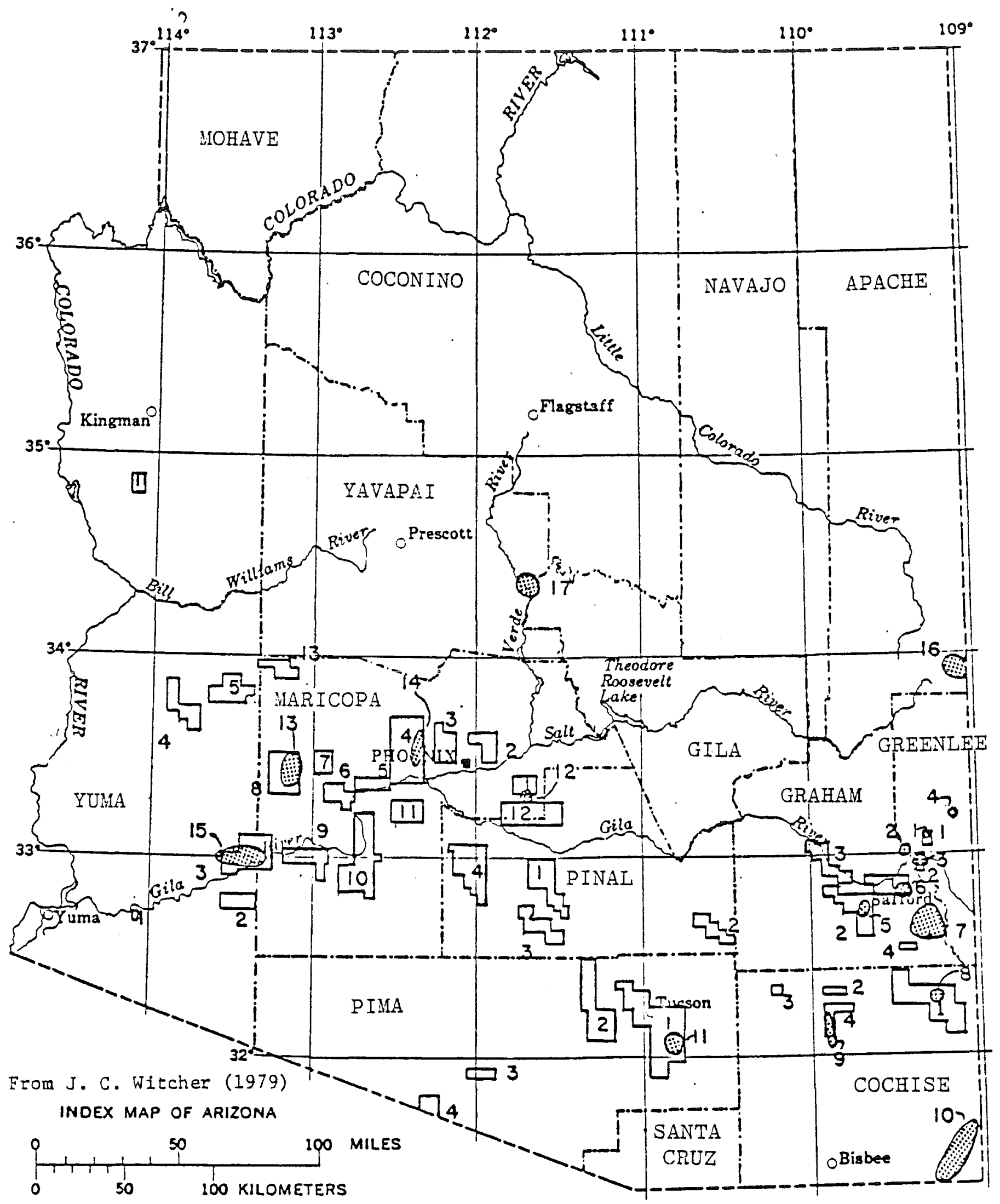

Figure 2: Arizona's Proven, Potential and Inferred Resources. 
TABLE 2: PROVEN AND POTENTIAL RESERVOIRS OF PINAL COUNTY OF LESS THAN 1.2 KM DEPTH Modified from Witcher (1979) Tr - Average Reservoir Temperature

\begin{tabular}{|c|c|c|c|c|c|c|c|}
\hline Area & Location & $\begin{array}{l}\text { Volume } \\
\left(\mathrm{km}^{3}\right)\end{array}$ & $\begin{array}{l}\text { Measured }\left({ }^{\circ} \mathrm{C}\right) \\
\text { Temperature }\end{array}$ & $\begin{array}{l}\text { Dep th } \\
(\mathrm{km})\end{array}$ & $\operatorname{Tr}\left({ }^{\circ} \mathrm{C}\right)$ & $\begin{array}{l}\text { Geothermometry } \\
\text { Temperature }\left({ }_{C}\right)\end{array}$ & Method \\
\hline 1 & $\mathrm{R} 5-8 \mathrm{~S}, \mathrm{R} 7-9 \mathrm{E}$ & 126.9 & $30-45$ & $<0.76$ & 55 & $40-80$ & Chalcedony \\
\hline 2 & $\mathrm{~T} 8-10 \mathrm{~S}, \mathrm{R} 16-18 \mathrm{E}$ & 61.9 & $30-45$ & $<0.31$ & 60 & $50-70$ & Chalcedony \\
\hline 3 & $\mathrm{~T} 8-9 \mathrm{~S}, \mathrm{R} 6-8 \mathrm{E}$ & 80.5 & $30-45$ & $<0.76$ & 55 & $40-80$ & Chalcedony \\
\hline 4 & $T 4-7 S, R 2-4 E$ & 164.1 & $30-40$ & $<0.46$ & 55 & - & $\begin{array}{l}\text { Reservoir Temp, for } \\
\text { Gradient }=35^{\circ} \mathrm{c} / \mathrm{km}\end{array}$ \\
\hline
\end{tabular}


the Coolidge area. Twelve wells in this area discharge water at less than $50^{\circ} \mathrm{C}\left(122^{\circ} \mathrm{F}\right)$; seven wells discharge water at greater than $50^{\circ} \mathrm{C}\left(122^{\circ} \mathrm{F}\right)$. Fluids discharged during a production test of a $2500-\mathrm{m}$ '(8200-ft) geothermal test well drilled in the Picacho Basin reached a maximum temperature of $82^{\circ} \mathrm{C}\left(180^{\circ} \mathrm{F}\right)$. This temperature is not sufficient for electric power production but could be applicable to space and process heating. A forthcoming state geothermal map compiled by the Arizona Bureau of Geology and Mineral Technology and published by the National Oceanographic and Atmospheric Administration will provide a complete and updated listing of data concerning thermal well and spring locations as well as temperature and depth estimates, flow rates and total dissolved solids. This map will be available in late 1981.

ECONOMY

\section{Population}

The 1980 population of Pinal County was 90,918. The total land area of 5,386 square miles give the county a population density of 17 persons per square mile. Ethnic breakdown of the population is 50 percent white, 36 percent Hispanic, 9 percent Indian and 4 percent black.

Growth

Historically, the population of Pinal County has grown at a 2.6 percent annual rate since 1950. Future projections place growth at a 1.6 percent annual rate to 2020. Figure 3 presents population projections for Pinal County.

Pinal County, situated between Maricopa and Pima counties, is predominantly rural. The major cities and their populations are listed in Table 3 . 


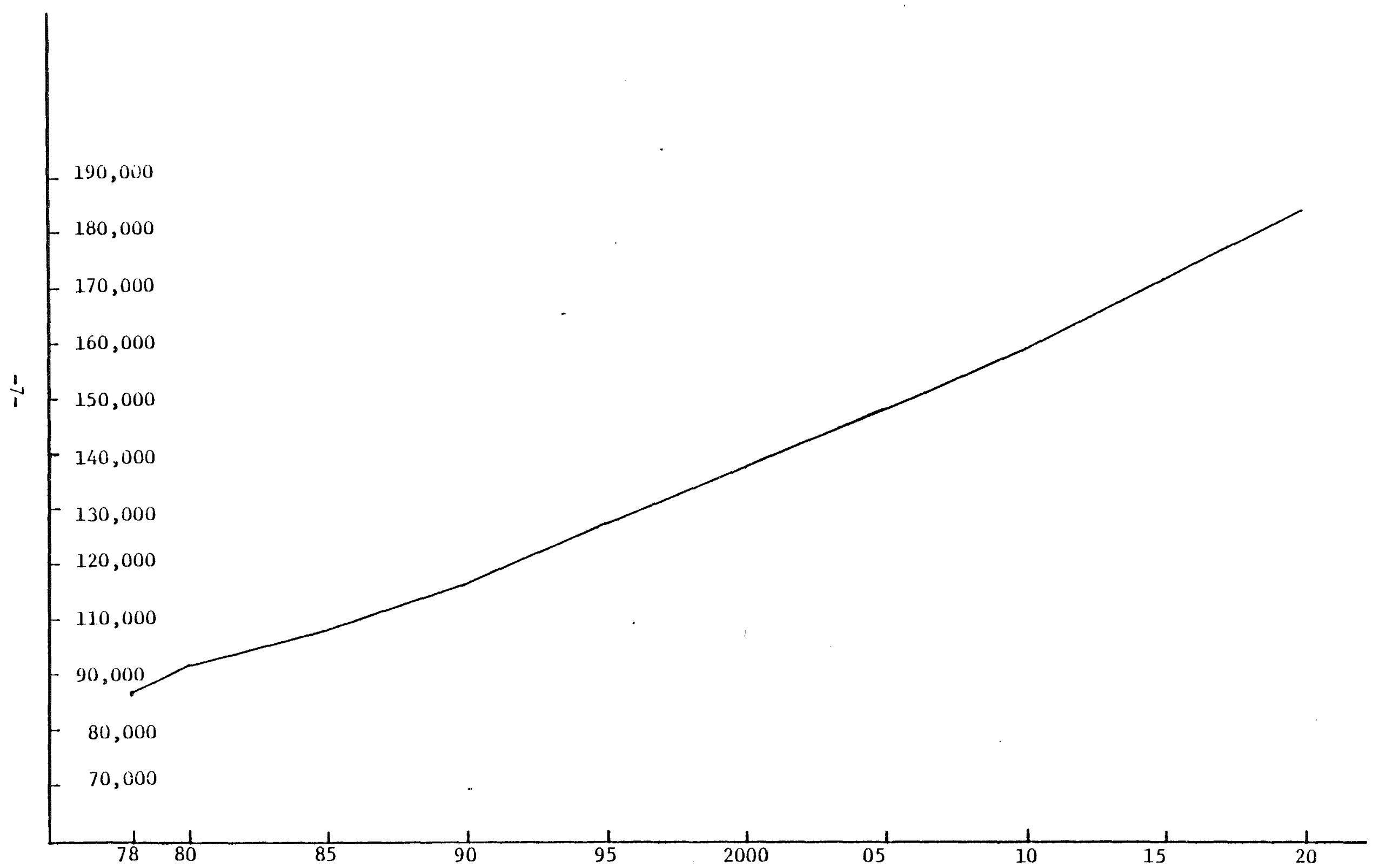

Figure 3: Population Projections for Pinal County.

Source: Technical Advisory Committee (DES) 
TABLE 3: MAJOR TOWNS IN PINAL COUNTY AND THEIR CURRENT AND PROJECTED POPULATIONS

\begin{tabular}{lrr}
\hline & 1979 & 2020 \\
\hline Apache Junction & 9,979 & 34,466 \\
Arizona City & 1,239 & 7,757 \\
Casa Grande & 16,908 & 33,539 \\
Coolidge & 7,427 & 13,949 \\
Eloy & 7,039 & 11,691 \\
Florence & 3,181 & 5,287 \\
Kearny & 2,703 & 5,189 \\
Marmoth & 2,228 & 3,316 \\
Oracle & 2,206 & 10,200 \\
San Manuel & 4,708 & 6,823 \\
Superior & 5,629 & 7,979 \\
\hline
\end{tabular}

Casa Grande, located between Phoenix and Tucson, is the largest city in Pinal County. It is expected to grow at a 1.8 percent annual rate with residential expansion occurring to the north and industrial expansion occurring to the west. Coolidge, the second largest city, is growing at a 1.5 percent annual rate with expansion occurring primarily to the west.

\section{Industry and Employment}

Pinal County is well balanced in terms of employment options. Mining, agriculture and manufacturing are all important sectors of the economy. Mining output contributed nearly $\$ 400$ million to the Pinal County economy in 1977. Estimated mining employment for 1979 in Pinal County was 6282 workers. Projections place mining employment at 9124 by the year 2000, an annual growth rate of 1.8 percent.

Value added by manufacturing amounted to $\$ 88$ million in 1977 , a 
decline from the 1972 level. Manufacturing employed 2320 persons in 1979; projections place manufacturing employment at 5891 by 2000 .

Total value of agricultural production in 1977 was $\$ 244$ million, down from the 1976 levels. Agriculture employed a total of 3782 workers in 1979. By 2000, the number of agricultural workers is expected to decline to 3014. Tourism is also somewhat important in Pinal County. In 1978, expenditures on tourism in Pinal County were estimated at over $\$ 28$ million.

Figure 4 summarizes employment in 1979. in Pinal County and provides projected employment information to the year 2000. According to the figures, the fastest growing employment sectors are mining and manufacturing.

\section{Income}

Personal income and per capita income are both projected to grow at real annual rates of 4.3 percent and 2.6 percent, respectively. The current level of personal income is $\$ 282$ million and per capita income is $\$ 3,228$. Both are in 1972 dollars.

\section{Other Economic Indicators}

Between 1268 and 1978, the value of retail sales steadily increased in Pinal County with a 251 percent increase occurring over the ten-year period. Bank deposits increased by 200 percent over the same time period. LAND OWNERSHIP

Figure 5 shows a general land ownership map for Pinal County. Acreage breakdowns for each ownership class are presented in Table 4. Procedures for acquiring surface and mineral rights depend upon which sector owns the land. 


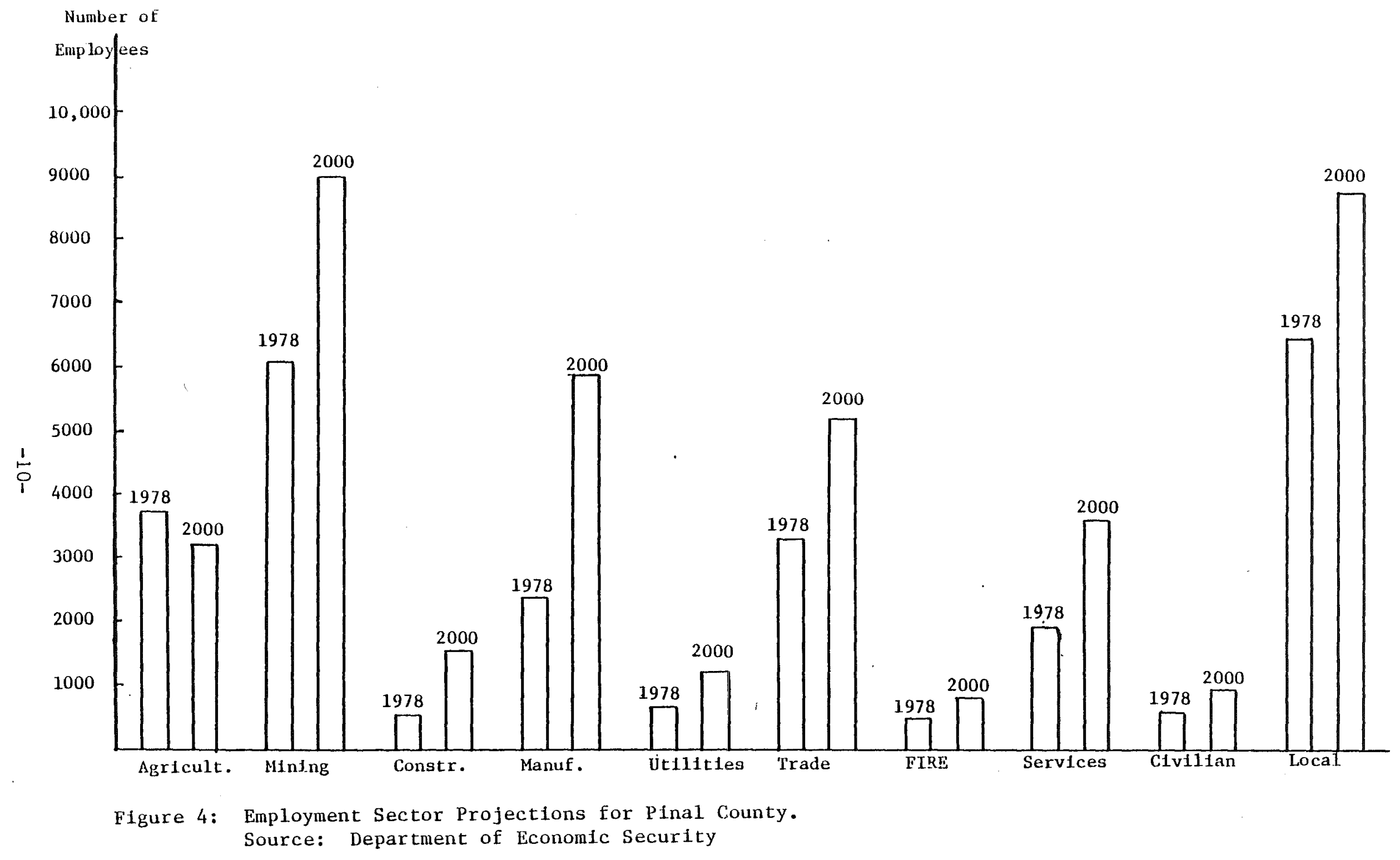



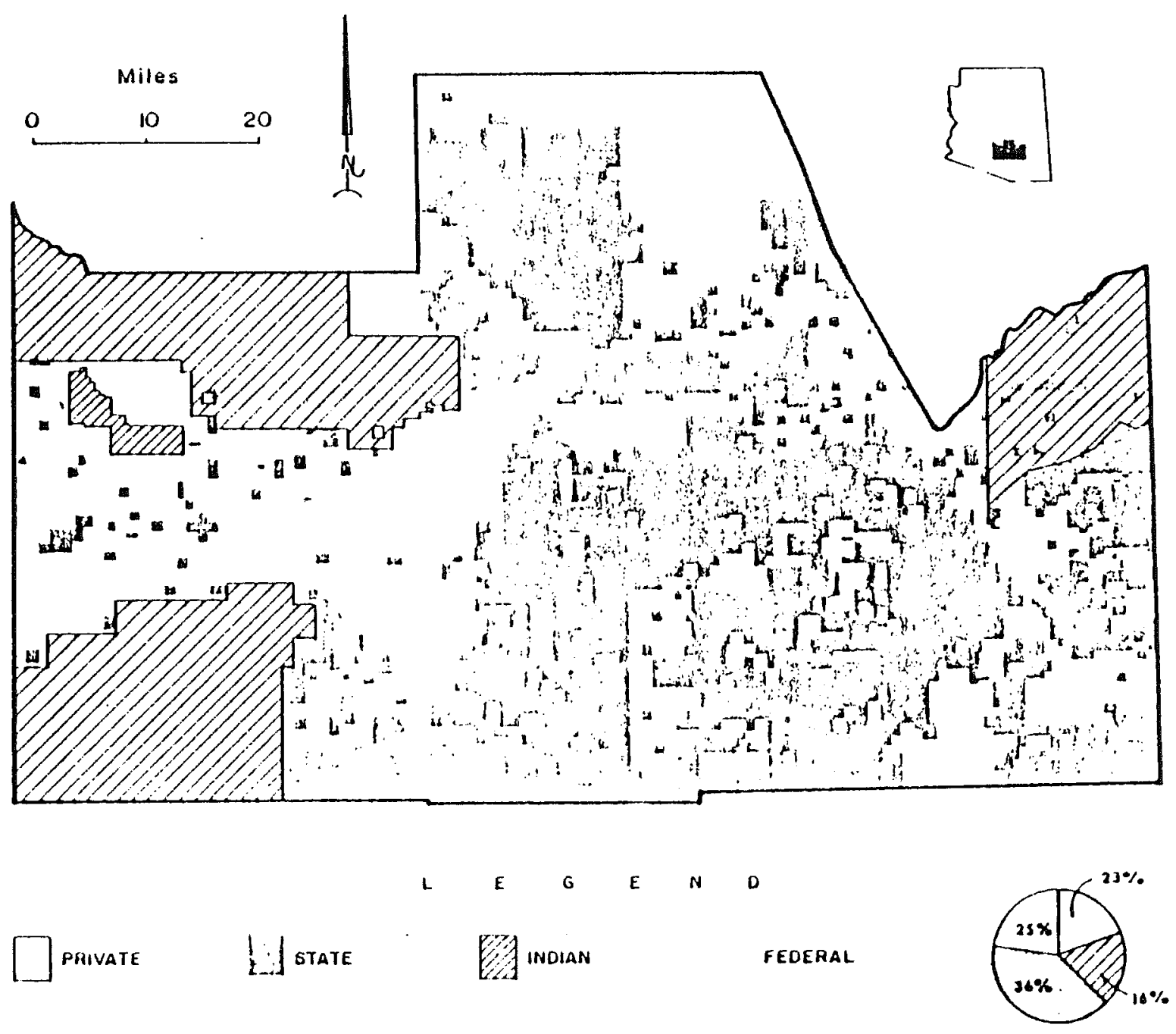

\section{PINAL COUNTY - LAND OWNERSHIP}

Figure 5: General Land Ownership Map For Pinal County. Source: Artzona Water Commission (1977) 
TABLE 4: BREAKDOWN OF LAND OWNERSHIP IN PINAL COUNTY

\begin{tabular}{lrr} 
& Acres & Percent of Total \\
\hline Federal & 791,660 & 23 \\
State & $1,239,120$ & 36 \\
Indian & 550,720 & 16 \\
Private & 860,500 & 25 \\
Total & $3,442,000$ & \\
\hline
\end{tabular}

\section{ENERGY USE}

Electricity, natural gas, distillate fuels and liquid petroleum gas, the energy types that the county most depends upon, are considered here. No attempt has been made to project the impact of the use of alternative energy sources such as wind power and solar energy.

Energy use and projections of energy use to the year 2020 for Pinal County are presented by user class in Table 5 .

TABLE 5: ENERGY-USE PROJECTIONS FOR PINAL COUNTY (1) (Trillion Btu)

\begin{tabular}{|c|c|c|c|c|}
\hline & $1978^{(2)}$ & $1985^{(3)}$ & $2000^{(3)}$ & $2020^{(3)}$ \\
\hline Residential & 2.19 & 2.0 & 1.8 & 2.0 \\
\hline Commercial & 2.58 & 2.4 & 2.1 & 2.3 \\
\hline Industrial & 5.0 & 4.6 & 4.0 & 4.4 \\
\hline Total & 9.77 & 9.0 & 7.9 & 8.7 \\
\hline
\end{tabular}

(1) Excludes transportation and conversion and transmission losses from the generation of electricity.

(2) 1978 figures for each sector were developed from Arizona Energy Use, 1978 compiled by the Division of Economic and Business Research, University of Arizona. 
(3) Projections were developed by the New Mexico Energy Institute by making use of growth rates for each user class.

The figures in Table 5 do not necessarily reflect what actual consumption will be but do show a general projection of energy-use trends. Energy use, determined by factors such as personal income and price of energy, is expected to decline in all three user classes due to consumer responsiveness to energy price increases. Table 6 shows 1979 energy prices for each user class per million Btu.

TABLE 6: ESTIMATED AVERAGE ENERGY PRICES BY USER CLASS, 1979 (Per Million Btu)

\begin{tabular}{lccc}
\hline & Residential & Commercial & \\
& & & Industrial $^{(2)}$ \\
\hline Electricity & $\$ 14.65-\$ 17.58$ & $\$ 11.70$ & $\$ 8.07$ \\
Natural Gas & $\$ 3.27$ & $\$ 2.48$ & $\$ 2.36$ \\
Liquid Petroleum Gas & $\$ 3.27-\$ 4.20$ & same & same \\
Distillates & $\$ 4.72-\$ 4.51$ & same & same \\
\hline
\end{tabular}

(1) Commercial: includes small industry

(2) Industrial: large industry

Source: Salt River Project Agr. Improvement and Power District, Arizona, Feb. 26, 1979; Arizona Public Service Co., Gas Division, 1979 data.

WATER

Figure 6 shows projections of water availability and use for Pinal County. The three alternative futures presented in the figure take into account a variety of factors such as population growth, industrial development and consumer habits and lifestyles that will have an effect on the future level of water use. The alternative futures summary in the figure 


\section{PINAL COUNTY \\ ALTERNATIVE FUTURES}

PROJECTED ALTERNATIVE WATER DEPLETIONS

AND OEPENOABLE SUPPLY

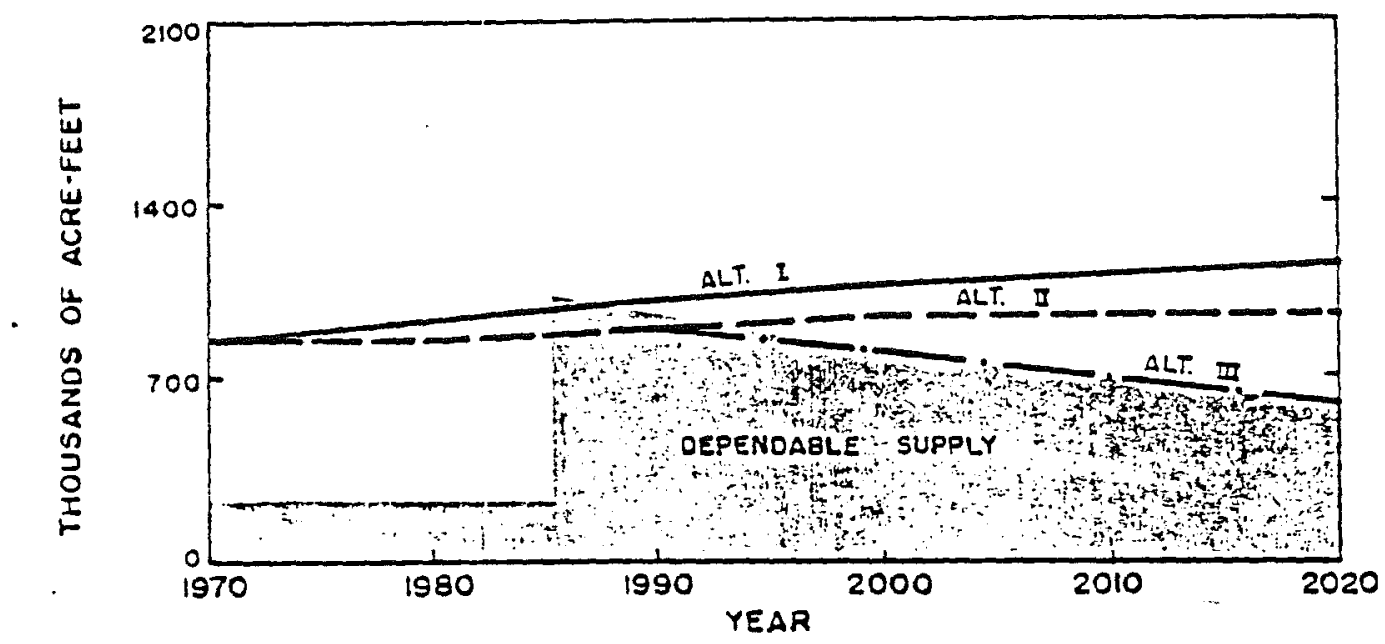

\section{ALTERNATIVE FUTURES SUMMARY}

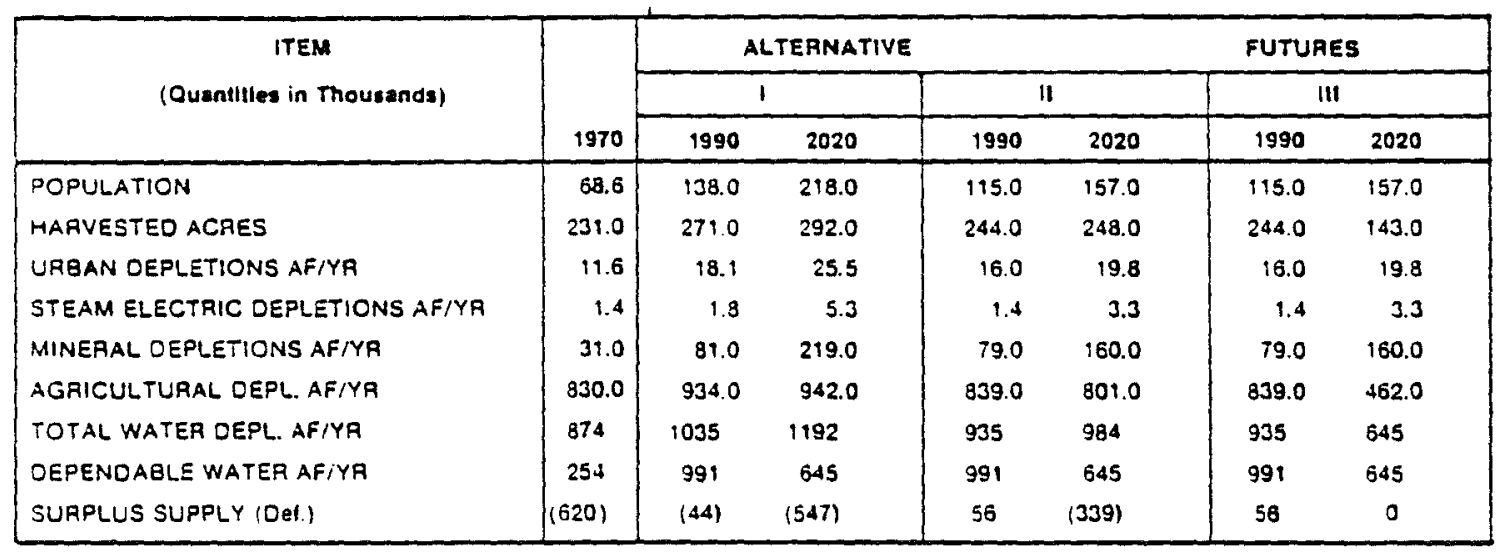

Figure 6: Projected Alternatives for Water Use in Pinal County。 Source: Arizona Water Commission (1977) 
shows that water use for agriculture accounts for 95 percent of projected water depletions in Pinal County; mineral production, accounting for less than four percent of total water depletions, is the county's second major water user. Both projected urban and steam electric water depletions are relatively small in comparison to total expected depletions.

In Pinal County, the assumed allocation of the Central Arizona Project (CAP) water is expected to completely satisfy the water needs for a short period of time after the CAP is complete. However, as agricultural water supplies from the Project decrease, the dependable supply available to the county will shrink rapidly. Under Alternative II in Figure 6, the dependable water supply is projected to decrease from 991,000 acre-feet in 1990 to 645,000 acre-feet in 2020. In 2020, annual deficiencies of 547,000 acrefeet and 339,000 acre-feet are predicted under Alternatives I and II, Iespectively; Alternative III predicts a balance between water supply and demand.

MATCHING GEOTHERMAL RESOURCES TO POTENTIAL USERS

One aim of the development plan is to define a time frame in which geothermal resources will realize commercial use. A time line was produced with the assistance of the New Mexico Energy Institute (NMEI). Information provided by the Solar Energy Research Institute identified industries within Pinal County having process heat requirements less than $105^{\circ} \mathrm{C}\left(221^{\circ} \mathrm{F}\right)$. Annual energy consumption was then estimated for each of these industries which are identified by a four-digit standard industrial code. This information, tabulated in Table 7 , was then used to model the introduction of geothermal energy into the process heat market. Figures 7 and 8 show time line results of this modeling under private development and under city 


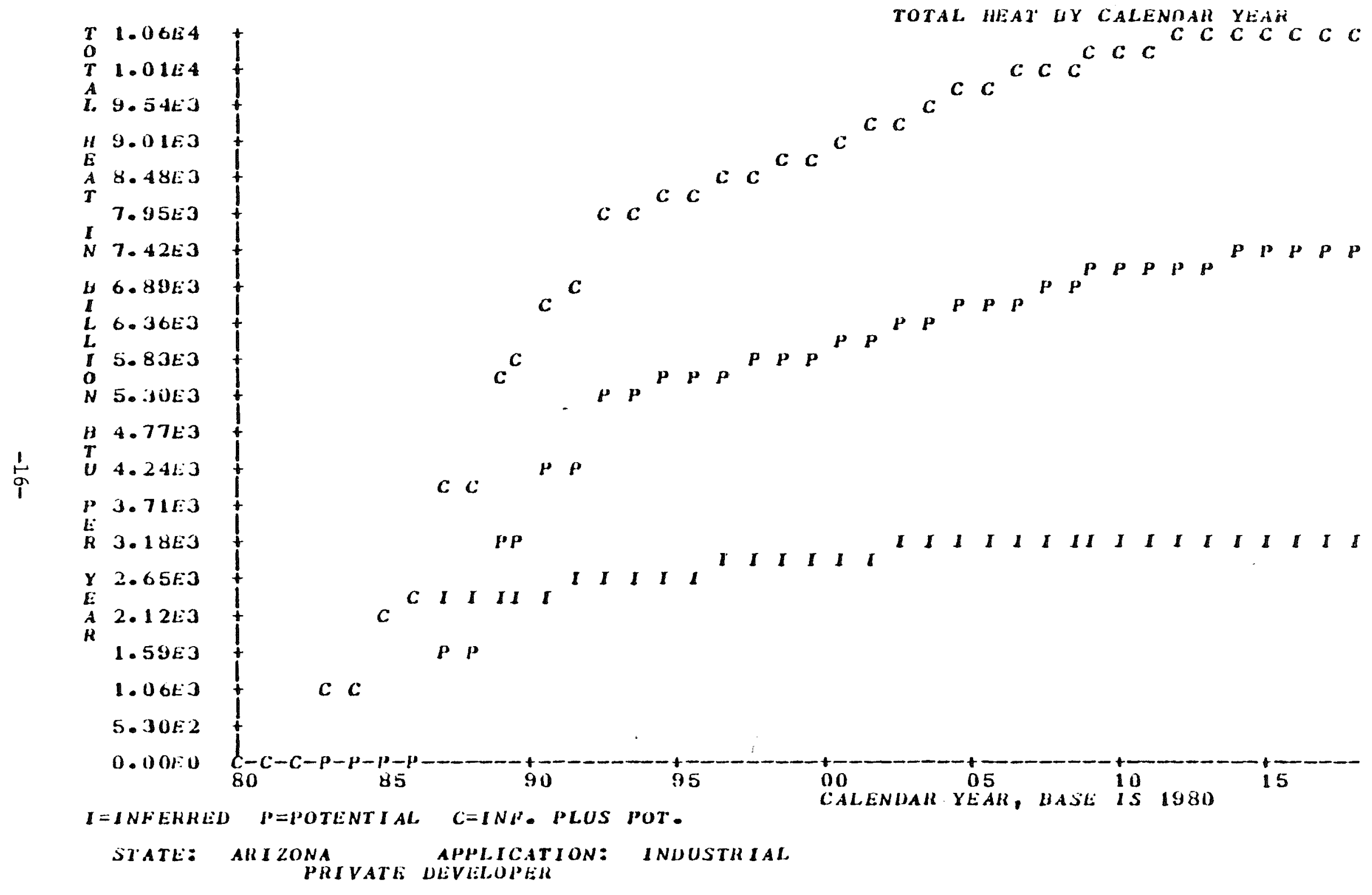

Figure 7: Projected Geothermal Heat on Line Under Private bevelopment. Source: New Mexico Energy Institute 


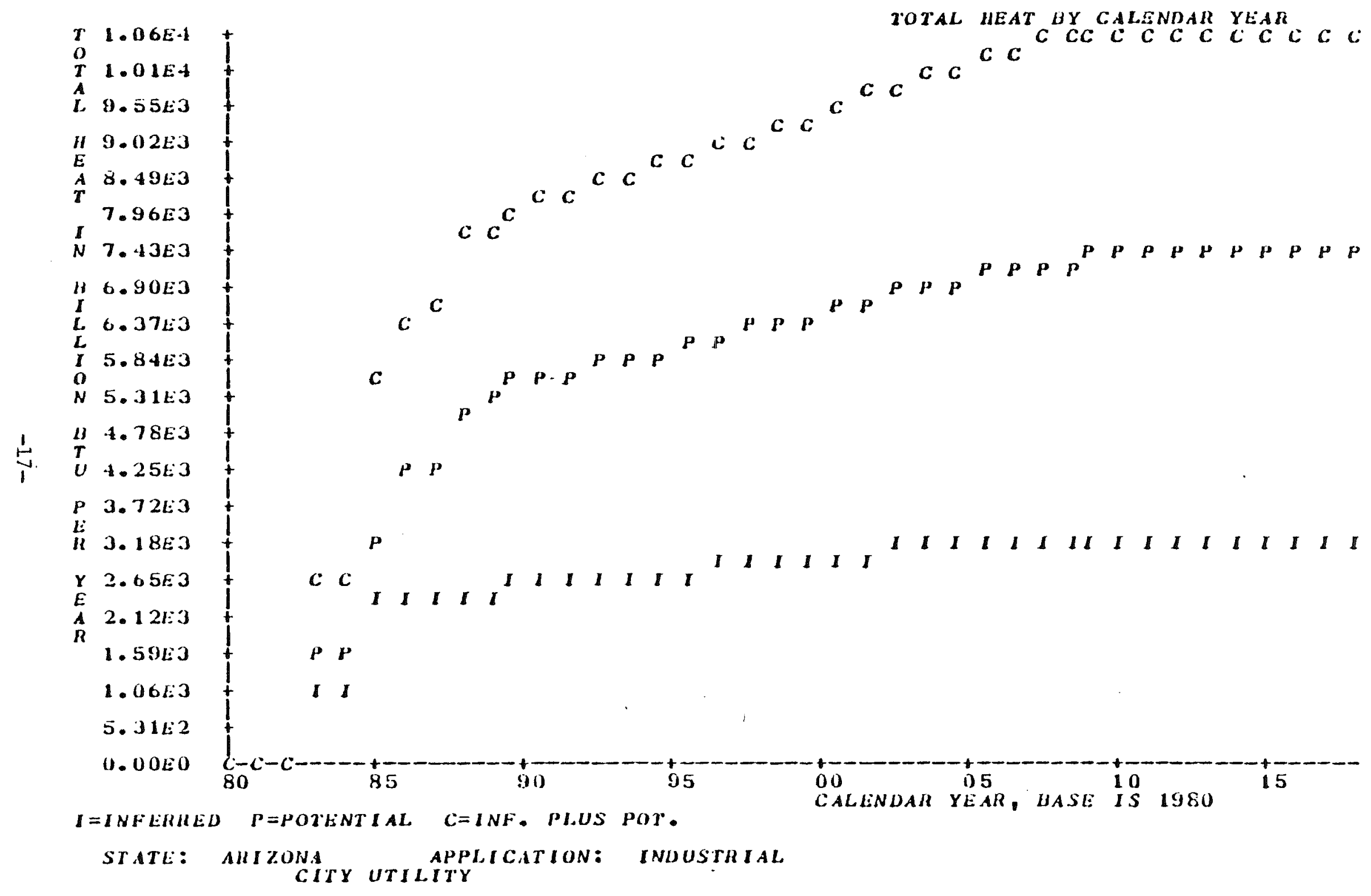

Figure 8: Projected Geothermal Heat on Line Under City Development. Source: New Mexico Energy Institute 
utility development, respectively. The differences primarily are due to variations in the cost of capital and tax liabilities for each type of development. Comparison of the figures shows that development of geothermal energy would occur faster under a city utility than it would under private development.

TABLE 7: ESTIMATED PROCESS HEAT ENERGY REQUIREMENTS Assumed Reservoir Temperature: $105^{\circ} \mathrm{C}$

\begin{tabular}{llll}
\hline $\begin{array}{c}\text { SIC } \\
\text { Code }\end{array}$ & $\begin{array}{c}\text { Number } \\
\text { of Firms }\end{array}$ & Description & $\begin{array}{c}\text { Energy Use } 12 \\
\text { Btu/yr x } 10^{12}\end{array}$ \\
\hline 2048 & 1 & Animal Feed & .323 \\
2086 & 1 & Soft Drinks & .0016 \\
2099 & 2 & Misc. Foods & .0033 \\
2519 & 1 & Fousehold Furniture & .1802 \\
2599 & 1 & Furniture and Fixtures & .1395 \\
3273 & 2 & Ready-Mix Concrete & .0058 \\
3441 & 1 & Structural Metal & .0164 \\
3443 & 1 & Boiler Shops & .0014 \\
3499 & 3 & Misc. Metal Products & .4526 \\
3911 & 1 & Jewelry & .0003 \\
& & Total & 1.127 \\
& & &
\end{tabular}

For purposes of comparison, the results of the modeling are presented in summary form in Table 8 in terms of barrels of oil replaced by geothermal energy annually.

The NMEI model is discussed more fully in Appendix A. 
TABLE 8: BARRELS OF OIL REPLACED BY GEOTHERMAL ENERGY PER YEAR

Process Heat Market

\begin{tabular}{lrrrr}
\hline & 1985 & 1990 & 2000 & 2020 \\
\hline Private Developer & 416,071 & $1,351,685$ & $1,767,589$ & $2,624,057$ \\
City Utility & $1,145,695$ & $1,561,599$ & $1,769,551$ & $2,624,057$ \\
\hline
\end{tabular}

Specific industries in Casa Grande which may be able to use geothermal energy for their space heating and/or process heat needs include Arizona Textile Corporation, Casa Grande Oil Mill, Casa Grande Valley Newspapers, Champion Products, Hexcel Corporation, Pinal Materials Company Incorporated and Skyline Corporation. Geothermal applications may also exist in Coolidge for Gila Enterprises and Gila River Indian Enterprises, Incorporated.

In matching geothermal resources to potential users, the agribusiness and agriculture industries within Final County were identified. Table 9 presents a list of the types of agribusiness industries in the county and the cities in which they are located. Many of these operations are located on or near a geothermal resource and probably could adopt geothermal energy.

TABLE 9: NUMBER OF FIRMS WITHIN VARIOUS AGRICULTURAL SECTORS FOR SOME CITIES IN PINAL COUNTY

\begin{tabular}{lccc}
\hline \multicolumn{1}{c}{ City } & $\begin{array}{c}\text { Agricultural } \\
\text { Chemicals }\end{array}$ & Feeds & $\begin{array}{c}\text { Cotton } \\
\text { Products }\end{array}$ \\
\hline Casa Grande & 4 & 3 & 7 \\
Coolidge & 1 & 1 & 2 \\
Eloy & & 1 & 3 \\
Maricopa & & 2 \\
Picacho & & 1 \\
\hline
\end{tabular}


Geothermal energy may also have some applications in the prepared feeds industry. The prepared feeds industry is comprised of plants primarily engaged in manufacturing prepared feeds and feed ingredients (alfalfa meal and feed supplements) for livestock and poultry. An estimated 52.8 percent of the total energy consumed by the industry in 197.2 was provided by natural gas; 10.6 percent was provided by fuel oil and 27.6 percent by purchased electricity. The remaining energy was obtained from other sources such as gasoline and diesel fuel consumed in harvesting and transporting. The prepared feeds industry is divided into five segments: prepared feeds, dehydrated alfalfa, sun-cured alfalfa, dehydrated grass and dehydrated citrus pulp. The prepared feeds segment, producing over 97 percent of the total output of the industry, is the most significant segment in terms of tons of feed processed. The type and amount of energy used in this segment for the various manufacturing processes are shown in Table 10 .

\section{TABLE 10: ENERGY USE IN THE PREPARED FEEDS SEGMENT}

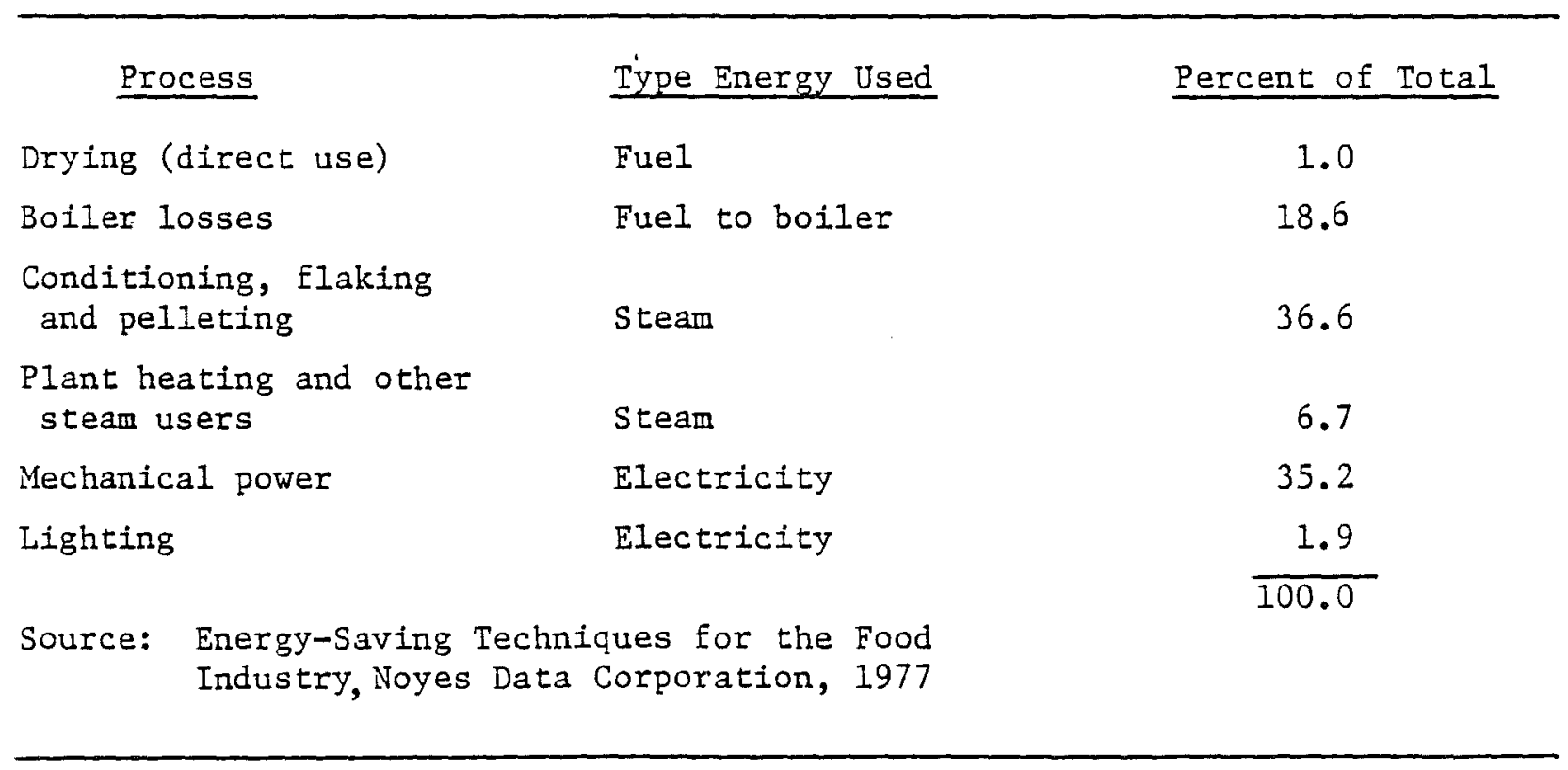


As shown in the table, the conditioning, flaking, and pelleting operations and the production of mechanical power consume the greatest amounts of energy. Less than seven percent of the total energy consumed is used for plant heating and other steam uses while only one percent is used for drying. There is one plant in Pinal County that falls under the prepared feeds industrial classification. Geothermal energy has potential applications in the drying process, in heating boiler feed water and in space heating. 


\section{Appendix A}

The New Mexico Energy Institute at New Mexico State University has developed a computer simulation model, BTHERM, to assess the economic feasibility of residential and commercial district space heating, hot water heating and industrial process heating using low temperature geothermal energy. Another model, CASH, was developed to depict the growth of geothermal energy on line over the next 40 years as a function of price of competing energy sources. A major assumption of these models is that geothermal energy must be price-competitive with the lowest-cost conventional energy source in order to assure market capture.

Development of a geothermal resource is characterized by large capital outlays, but a long-term geothermal investment has the potential to provide relatively inexpensive energy at a stable price. Unlike natural gas and electricity, however, geothermal energy is an unknown energy involving certain risks such as price and reservoir life and the need for back-up systems. An analysis of the costs and economic competitiveness of geothermal energy must take these uncertainties into account. Thus, costs may be overestimated so that the benefits will not be overstated.

BTHERM models the residential, commercial and industrial sectors

of a typical city, each sector having unique energy costs and energy system physical parameters as well as different growth rates. The model possesses the ability to model each sector individually and can analyze the application of geothermal energy to new growth only, to conversion of existing structures or to a combination of both. The model also has the capability to model both private and city-owned utility development of the geothermal resource. Output of the model includes the levelized price per million Btu of 
delivered energy, the discounted present value of investment necessary and the undiscounted values of investments for policy studies. Also, from input of the price and price growth rate of conventional energy, the model determines the discounted or undiscounted values for federal and state taxes, tax credits, royalty rates, property taxes and consumer savings due to conversion from conventional energy to geothermal.

Certain limitations of the model have already been suggested. Costs, for example, may be overestimated due to safeguards built into the model to take into account the risks associated with geothermal energy. This overestimation of costs might result in the exclusion of a potential use of geothermal energy. Another limitation is that the price of natural gas is taken as the price of competitive (conventional) energy, but not all users have access to natural gas.

The output of the model is not a substitute for detailed engineering design studies but it is useful for determining order-of-magnitude costs and potential benefits of geothermal energy development. 


\section{BIBLIOGRAPHY}

References used in preparing the Area Development Plans

Arizona Agricultural Statistics 1978, 1979: Phoenix, Arizona, Arizona Crop and Iivestock Reporting Service, $68 \mathrm{p}$.

Arizona Community Profiles, 1981: Phoenix, Arizona, Research Program, Arizona Office of Economic Planning and Development.

Arizona Statistical Review, 1979: Phoenix, Arizona, Valley National Bank of Arizona, $72 \mathrm{p}$.

Brown, R., 1978, Industrial Process Heat Demand Balance: Golden, Colorado, Solar Energy Research Institute, unpublished draft.

Climatograph of U.S. No. 81 Arizona, 1978: Asheville, North Carolina, National Climate Center.

Dunn, D. and Cox, D.C., 1979, Papers in Community Development No. 2 - SocioEconomic Indicators for Small Towns: Tucson, Arizona, Rural Information Center, $58 \mathrm{p}$.

Energy Analysis of 108 Industrial Processes, 1979: Philadelphia, Pennsylvania, Drexel Jniversity.

Energy-Saving Techniques for the Food Industry, 1977, M.E. Casper, editor: Park Ridge, New Jersey, Noyes Data Corporation, 657 p.

Frank, H.J., 1977, Arizona Energy Inventory: 1977: Jniversity of Arizona, Tucson, $100 \mathrm{p}$.

Gerber, L.A., Worden, M.A., and Dunn, D., 1980, Papers in Comunity Deve1opment No. 5 - Safford, Arizona: A Trade Area Analysis: Tucson, Arizona, Rural Information Center, $76 \mathrm{p}$.

Gibson, I.J., Worden, M.A., and Solot, M.S., 1979, Papers in Comminity Development No. 1 - A Citizen's Handbook for Evaluating Community Impacts: Tucson, Arizona, Rural Information Center, 65 p.

Hodgson, M.L., 1978, Arizona Job Scene 1985: A Labor Marker Information Publication of the Arizona Department of Economic Security, $133 \mathrm{p}$. 
Industrial Waste Heat Survey, 1978, Rocket Research Company.

Inside Phoenix 1979, 1979: Phoenix, Arizona, Phoenix Newspapers, Inc., 152 p.

Inside Phoenix 1981, 1981: Phoenix, Arizona, Phoenix Newspapers, Inc., 128 p.

1981 Directory of Arizona Manufacturers, 1981: Phoenix, Artzona, Phoenix Metropolitan Chamber of Comerce, 200 p.

Phase II - Arizona State Water Plan: Alternative Future, 1977: Phoenix, Arizona, Arizona Water Commission, $145 \mathrm{p}$.

r

Population, Employment and Income Projections for Arizona Counties 1977 2000, July 1978 \& 1979: Arizona Department of Economic Security.

Zopulation Estimates of Arizona as of July 1, 1979: Phoenix, Arizona, Arizona Department of Economic Security Report No. 12, 66 p.

Statistical Report for Financial Analysis 1969 - 1979: Phoenix, Arizona, Arizona Public Service Company, $24 \mathrm{p}$.

Stone, C., 1980, Preliminary Assessment of the Geothermal Potential at the Papago Farns, Papago Indian Reservation, Arizona: State of Arizona Bureau of Geology and Mineral Technology Open-File Report 80-6, 62 p.

Stone, C., 1981, A Preliminary Assessment of the Geothermal Resource Potential of the Yuma Area, Arizona: State of Arizona Bureau of Geology and Mineral Technology Open-File Report 81-4, $28 \mathrm{p}$.

Survey and Analysis of Solar Energy Process Heat Opportunities in Arizona, 1979: University of Arizona, Department of Nuclear Energy, Energy Management and Policy Analysis Group, Final Report prepared for Arizona Solar Energy Research Commission under Office of Economic Planning and Development Contract No. 458-78

Swanberg, C.A., Morgan, P., Stoyer, C.H., and others, 1977, An Appraisal Study of the Geothemal Resources of Arizona and Adjacent Areas in New Mexico and Utah and Their Value for Desalination and other Uses: New Mexico Energy Institute Report No. 6, 76 p. 
Tucson Trends 1980, 1980: Tucson, Arizona, Valley National Bank of Arizona and Tucson Newspapers Inc, 88 p.

Witcher, J.C., 1979, Proven, Potential and Inferred Geothemal Resources of Arizona and Their Heat Contents: State of Arizona Bureau of Geology and Mineral Technology Open-File Report $70^{9}$ ), $65 \mathrm{p}$.

Witcher, J.C., 1981, Geothermal Energy Potential of the Lower San Francisco River Region, Arizona: U.S. Geological Survey Open-File Report 81-7, $135 \mathrm{pe}$ 